\title{
PENERAPAN MODEL SKRIP KOOPERATIF PADA MATA PELAJARAN ILMU PENGETAHUAN SOSIAL
}

\author{
Udin Wahyudin \\ SMPN 2 Jamblang Cirebon, Indonesia \\ wahyudin.udin29@gmail.com
}

\begin{abstract}
The problem faced in this research is the lack of students' ability to understand the material. This study aims to improve the ability of IXD grade students of SMP Negeri 2 Jamblang in understanding the explanation of resource persons in social studies subjects by applying the Cooperative Script Model. This Classroom Action Research (CAR) was carried out in IXD grade SMP Negeri 2 Jamblang, Cirebon Regency. The activities were carried out in two action cycles. The results showed an increase in the ability of students to understand the subject matter of Social Sciences. So it can be concluded that the Cooperative Script model in social studies learning can improve students' understanding of Class IXD SMP Negeri 2 Jamblang, Cirebon Regency.
\end{abstract}

Keywords: student understanding, cooperative scripts

\section{ABSTRAK}

Permasalahan yang dihadapi dalam penelitian ini adalah masih kurangnya kemampuan siswa dalam memahami materi. Penelitian ini bertujuan untuk meningkatkan kemampuan siswa kelas IXD SMP Negeri 2 Jamblang dalam memahami Penjelasan Narasumber pada mata pelajaran IPS dengan penerapan Model Skrip Kooperatif. Penelitian Tindakan Kelas (PTK) ini dilaksanakan pada kelas IXD SMP Negeri 2 Jamblang Kabupaten Cirebon. Kegiatan dilakukan sebanyak dua siklus tindakan. Hasil penelitian menunjukkan terjadi peningkatan kemampuan siswa dalam memahami materi mata pelajaran Ilmu Pengetahuan Sosial. Sehingga dapat disimpulkan bahwa model Skrip Kooperatif dalam pembelajaran IPS dapat Meningkatkan Pemahaman siswa Kelas IXD SMP Negeri 2 Jamblang Kabupaten Cirebon.

Kata Kunci : pemahaman siswa, kooperatif skrip

\begin{tabular}{l|l|l} 
Submitted Apr 21, 20xx & Revised Nov 11, 20xx & Accepted Nov 28, 20xx
\end{tabular}

\section{Pendahuluan}

Ilmu pengetahuan sosial adalah ilmu pengetahuan yang mengkaji realita kondisi sosial yang ada di lingkungan siswa, sehingga dengan memberikan pendidikan IPS diharapkan dapat melahirkan warga negara yang baik dan bertanggung jawab terhadap bangsa dan negaranya (Giri, Suarni, \& Arini, 2018). IPS hendaknya dikembangkan berdasarkan realita kondisi sosial budaya yang ada di lingkungan siswa, sehingga dengan ini akan dapat membina warga negara yang baik yang mampu memahami dan menelaah secara kritis kehidupan sosial baik di masyarakatnya, negara, maupun dunia. Dalam pelaksanaanya, pembelajaran IPS tidak cukup hanya dengan menyampaikan materi dan siswa hanya mendengarkan materi yang disampaikan tetapi pembelajaran IPS harus melibatkan siswa dalam pembelajaran. Peserta didik dilatih untuk berpikir luas dan mendalam menangkap dan memahami materi yang disajikan guru. Pendidikan IPS sebagai bidang studi yang diberikan pada jenjang pendidikan di lingkungan persekolahan, bukan hanya memberikan bekal pengetahuan saja, tetapi juga memberikan bekal nilai dan sikap serta keterampilan dalam kehidupan peserta didik di masyarakat, bangsa dan negara dalam berbagai karakteristik (Susanto, 2013). Pendidikan IPS diharapkan dapat 
menjadi wahana bagi peserta didik untuk mempelajari diri sendiri dan di sekitarnya, serta prospek pengembangan lebih lanjut dalam penerapan dalam kehidupan sehari-hari.

Namun harus diakui bahwa kompetensi dan kompetensi dasar pada mata pelajaran Ilmu Pengetahuan Sosial (IPS) masih jauh yang diharapkan tercapai. Penyebab utama dari tidak tercapainya prestasi belajar yaitu metode pembelajaran yang diterapkan terlalu monoton dan menjemuhkan bagi para siswa. Akibatnya siswa dalam menangkap setiap pelajaran yang disampaikan oleh guru bengong, malas, bosan dan kurang bergairah. Terbukti dari hasil observasi, nilai evaluasi belajar IPS siswa Kelas IX D SMP Negeri 2 Jamblang Kabupten Cirebon pada ulangan arian semester ganjil tahun 2019/2016 hanya 20,9 \% (9 siswa) dari 43 siswa yang dinilai sudah memahami tentang materi pembelajaran "Uang dan Lembaga Keuangan” yang dipergunakan untuk mengukur pemahaman siswa dalam kelas.

Sejalan dengan persoalan diatas dalam proses belajar mengajar Ilmu Pengetahuan Sosial (IPS) atau lainnya diperlukan metode-metode baru yang inovatif yang dapat membawa siswa kearah belajar yang lebih baik dan bersemangat tinggi. Oleh karena itu harus dicari metode-metode baru yang tepat dan dapat menarik siswa kearah belajar yang lebih baik dan bersemangat dalam belajar Ilmu Pengetahuan Sosial (IPS). Penerapan model pembelajaran yang tepat diharapkan dapat mengatasi rendahnya hasil belajar siswa dengan menciptakan suasana yang menyebabkan siswa termotivasi dan aktif dalam belajar. Jika siswa aktif, maka diharapkan hasil belajar siswa dapat meningkat (Aryati, 2017). Agar pembelajaran Ilmu Pengetahuan Sosial (IPS) menjadi bermakna dan berjalan sebagaimana yang diharapkan serta memberikan pengalaman belajar baru bagi peserta didik, maka sangat diperlukan model pembelajaran kooperatif (Lathifah, 2014). Pendekatan pembelajaran ini salah satunya menekankan kepada bagaimana belajar di sekolah, yaitu Model Skrip Kooperatif. Model pembelajaran kooperatif merupakan salah satu model pembelajaran yang sangat popular untuk diterapkan dalam berbagai bidang studi (Kusumawati \& Sukidi, 2014). Model pembelajaran Kooperatif didefinisikan sebagai penggunaan pembelajaran kelompok kecil (Adi, Phang, \& Yusof, 2012) sehingga siswa bekerja sama untuk memaksimalkan diri mereka sendiri, berpartisipasi langsung (Sriarunrasmee, Suwannatthachote, \& Dachakupt, 2015) dan terlibat secara aktif dalam pembelajaran (Johnson \& Johnson, 1999) serta belajar bersama satu sama lain untuk mencapai tujuan pembelajaran (Oxford, 1997)(Buchs, Gilles, Dutrévis, \& Butera, 2011) memecahkan masalah, menyelesaikan tugas atau membuat produk (Laal \& Ghodsi, 2012)(Laal, Khattami-Kermanshahi, \& Laal, 2014).

Model pembelajaran kooperatif terdiri dari berbagai tipe, salah satunya yaitu model pembelajaran Cooperative Script. Model pembelajaran ini dapat diterapkan pada pembelajaran yang bersifat kognitif, karena setiap peserta didik nantinya diberikan materi ajar secara lengkap, dibagi berpasang-pasangan dan masing-masing dari mereka bergantian secara lisan mengintisarikan materi yang telah diberikan, dan pasangan lainnya mengoreksi apakah benar pernyataan yang diungkapkan oleh temannya tersebut atau tidak (Meilani \& Sutarni, 2016). Pada pembelajaran Cooperative Script terjadi kesepakatan antara siswa tentang aturan-aturan dalam berkolaborasi, yaitu siswa satu dengan yang lainnya bersepakat untuk menjalankan peran masing-masing (Darojat, Ani, \& Suyadi, 2018). Model pembelajaran cooperative script mempunyai peran strategis dalam upaya mendongkrak hasil belajar siswa. Dalam penerapannya guru menyesuaikan dengan kondisi kebutuhan siswa, sehingga guru diharapkan mampu menyampaikan materi dengan tepat tanpa mengakibatkan siswa mengalami 
kebosanan (Salamiah, 2018). Guru dapat mengimplementasikan sebuah model pembelajaran yang mengharuskan siswa melakukan belajar dengan cara berpasangan (cooperative script) yang diharapkan mampu meningkatkan keaktifan dan prestasi belajar (Suryana, 2017).

\section{Metode Penelitian}

Metode yang digunakan dalam penelitian ini adalah penelitian tindakan kelas. Penelitian Tindakan Kelas merupakan penelitian tindakan dalam bidang pendidikan yang dilaksananakan dalam kawasan kelas dengan tujuan untuk memperbaiki dan atau meningkatkan kualitas pembelajaran (Kasbolah, 2001). Penelitian tindakan kelas merupakan suatu pencermatan terhadap kegiatan yang sengaja dimunculkan, dan terjadi dalam sebuah kelas (Arikunto, 2006). Penelitian tindakan kelas dilakukan oleh seorang guru di dalam kelasnya sendiri melalui refleksi diri, dengan tujuan untuk memperbaiki kinerjanya sebagai guru, sehingga hasil belajar siswa menjadi meningkat (Wardani, 2007).

Penelitian tindakan kelas ini dilaksanakan di kelas IXD SMP Negeri 2 Jamblang Kabupaten Cirebon, hal ini disebabkan karena perlu adanya penelitian tentang pendekatan pembelajaran yang paling efektif sehingga prestasi dalam mata pelajaran Ilmu Pengetahuan Sosial siswa tersebut sesuai apa yang diharapkan, kemudahan dalam pelaksanaan penelitian karena peneliti merupakan guru di SMP Negeri 2 Jamblang Kabupaten Cirebon, Adanya ikatan bathin yang baik antara peneliti dengan seluruh warga sekolah.

Penelitian tindakan kelas ini dilaksanakan pada jam mata pelajaran IPS. Yaitu hari Rabu, 02 Oktober 2019 untuk siklus I, dan tanggal 09 Oktober 2019 untuk siklus II. Subjek penelitian tindakan kelas ini adalah siswa kelas IXD SMP Negeri 2 Jamblang Kabupaten Cirebon tahun ajaran 2019 - 2020. Dalam pengambilan subyek penelitian ini didasarkan pada kondisi kelas IXD secara keseluruhan berjumlah 35 siswa. Alat yang dipergunakan untuk mengumpulkan data adalah: Tes Tertulis. Untuk mengetahui kemampuan siswa dalam penguasaan materi yang dijadikan objek penelitian ini, peneliti menggunakan alat yang berupa tes tertulis yang telah dirancang oleh peneliti sesuai dengan tujuan yang telah tertuang di dalam kisi-kisi soal. Tes tertulis digunakan untuk mengumpulkan data yang berkenaan dengan hasil penguasaan materi "Uang dan Lembaga Keuangan" yang telah dikuasai siswa, setelah mengikuti suatu proses perlakuan yang dilakukan oleh peneliti, sehingga diperoleh hasil yang akurat dan dapat digambarkan secara jelas kemampuan siswa dalam menguasai materi tersebut.

\section{Hasil dan Pembahasan}

Penelitian pada siklus ini dilakukan dengan: a) mengidentifikasi permasalahan menyangkut bahan pelajaran yang digunakan, strategi pembelajaran yang biasa digunakan. Pada siklus ini menggunakan pendekatan konvensional, b). menyajikan materi pembelajaran "Uang dan Lembaga Keuangan", c). melakukan pengamatan dengan menggunakan observasi dan pemotretan, d). mengukur dampak pendekatan konvensional digunakan daftar aktivitas siswa.

Dalam melakukan perencanaan penelitian, penulis mengadakan kolaborasi dengan guru lain dalam menyusun rencana penelitian, yang meliputi: 1) tujuan pembelajaran, 2) kompetensi dan materi pembelajaran, 3) strategi pembelajaran berupa Model dan media yang digunakan, serta sumber belajar dan 4) evaluasi hasil belajar. 
Dalam kegiatan tindakan, Guru membagi kelompok dalam beberapa kelompok besar. Guru memberikan arahan bahwa siswa bertanggung jawab atas segala sesuatu di dalam kelompoknya, seperti milik mereka sendiri,. Siswa haruslah melihat bahwa semua anggota di dalam kelompoknya memiliki tujuan yang sama,

Pada awal pembelajaran, observasi dilakukan terhadap guru membuka pelajaran seperti apersepsi terhadap materi yang akan dibahas dan memberikan motivasi kepada siswa. Pada siklus pertama observer kinerja guru untuk kegiatan pendahuluan dinilai rata-rata baik, namun untuk pemecahan masalah, mengelola informasi, implementasi hasil, buku pelajaran yang relevan masih kurang.

Dari hasil observasi pembelajaran IPS dengan model Skrip kooperatif diperoleh bahwa keberhasilan pembelajaran pada siklus I sebesar 46\%. Jadi, dapat disimpulkan bahwa kemampuan guru dalam mengajar, sikap guru dalam pelajaran, penguasaan materi, proses pembelajaran, pemakaian media, kemampuan menutup pelajaran dinilai cukup ( C ) oleh observer. Adapun dari hasil observasi aktivitas siswa saat mengikuti pembelajaran pada siklus I diperoleh keberhasilan sebesar 52\%. Dengan demikian, dapat disimpulkan bahwa perhatian siswa dalam Kegiatan Belajar Mengajar (KBM), keberanian, jawaban siswa, kesungguhan dalam mengikuti pelajaran, keseriusan mengerjakan soal ringan dan berat dinilai observer adalah Cukup ( C ).

Pada siklus II, hasil observasi pembelajaran IPS mencapai keberhasilan sebesar 89\%. Dapat disimpulkan bahwa kemampuan guru dalam membuka pelajaran, sikap guru dalam proses pembelajaran, penguasaan materi, kegiatan proses pembelajaran, pemakaian media, kemampuan menutup pelajaran dinilai baik (B) oleh observer. Adapun aktivitas siswa sebesar $76 \%$ sehingga dapat disimpulkan bahwa perhatian siswa dalam KBM, keberanian, jawaban siswa, kesungguhan dalam mengikuti pelajaran, keseriusan mengerjakan soal ringan dan berat dinilai observer baik (B) kesanggupan, jawaban dan keberanian siswa dinilai sangat baik (B).

Setelah dilakukan penelitian tindakan kelas dari setiap siklusnya dapat dilihat adanya perubahan hasil belajar, yaitu hasil belajar siswa meningkat dari siklus I hingga ke siklus II yang cukup signifikan.

Tabel 1 Nilai Evaluasi Belajar Siswa pada Setiap Siklus

\begin{tabular}{|c|c|c|c|c|c|}
\hline No & $\mathrm{N}$ a m a & $\mathbf{L} / \mathbf{P}$ & Pra test & SiKLUS 1 & Siklus II \\
\hline 1 & Aksudi & $\mathrm{L}$ & 60 & 80 & 90 \\
\hline 2 & Abung Nurcolis & $\mathrm{L}$ & 60 & 70 & 80 \\
\hline 3 & Kubjaya & $\mathrm{L}$ & 50 & 60 & 70 \\
\hline 4 & Muslik & $\mathrm{L}$ & 60 & 70 & 80 \\
\hline 5 & Moh.Arifin & $\mathrm{L}$ & 60 & 70 & 80 \\
\hline 6 & Riyan & $\mathrm{L}$ & 50 & 70 & 80 \\
\hline 7 & Surtini & $\mathrm{P}$ & 40 & 70 & 80 \\
\hline 8 & Siti Murlyani & $\mathrm{P}$ & 70 & 80 & 90 \\
\hline 9 & Widi Saputri & $\mathrm{L}$ & 40 & 60 & 80 \\
\hline 10 & Moh. Saputri & $\mathrm{L}$ & 60 & 70 & 80 \\
\hline 11 & Isnaeni & $\mathrm{L}$ & 70 & 70 & 90 \\
\hline 12 & Suleman & $\mathrm{L}$ & 60 & 70 & 80 \\
\hline 13 & Asri Apriliya & $\mathrm{P}$ & 60 & 70 & 80 \\
\hline 14 & Fitriyah & $\mathrm{P}$ & 60 & 70 & 80 \\
\hline 15 & Aded Siti Jubaedah & $\mathrm{P}$ & 60 & 60 & 90 \\
\hline 16 & Aruludin Muzaqi & $\mathrm{L}$ & 40 & 60 & 80 \\
\hline 17 & Ani Romalasari & $\mathrm{P}$ & 50 & 80 & 90 \\
\hline
\end{tabular}




\begin{tabular}{|c|c|c|c|c|c|}
\hline 18 & Ade Firmansyah & $\mathrm{L}$ & 50 & 70 & 80 \\
\hline 19 & Dian Islami & $\mathrm{P}$ & 60 & 80 & 90 \\
\hline 20 & Denok Khoirunisa & $\mathrm{P}$ & 66 & 70 & 70 \\
\hline 21 & Fitri Sulastri & $\mathrm{P}$ & 60 & 70 & 80 \\
\hline 22 & Khoirudin & $\mathrm{L}$ & 60 & 80 & 80 \\
\hline 23 & Khalimatus S. & $\mathrm{P}$ & 60 & 70 & 80 \\
\hline 24 & Khoirunisa & $\mathrm{P}$ & 40 & 60 & 70 \\
\hline 25 & Madi & $\mathrm{L}$ & 50 & 60 & 90 \\
\hline 26 & Moh. Arton & $\mathrm{L}$ & 50 & 70 & 80 \\
\hline 27 & Moh. Syamsul A. & $\mathrm{L}$ & 50 & 70 & 90 \\
\hline 28 & Nasukha & $\mathrm{P}$ & 60 & 70 & 80 \\
\hline 29 & Nur Hapiyah & $\mathrm{P}$ & 50 & 70 & 80 \\
\hline 30 & Nur Aeni & $\mathrm{P}$ & 60 & 70 & 80 \\
\hline 31 & Nur Fiani & $\mathrm{P}$ & 70 & 80 & 90 \\
\hline 32 & Nur Khasanah A. & $\mathrm{P}$ & 50 & 60 & 70 \\
\hline 33 & Nur Khasanah B & $\mathrm{P}$ & 50 & 70 & 80 \\
\hline 34 & Nur Khofifah & $\mathrm{P}$ & 60 & 70 & 90 \\
\hline 35 & Sinta Nuriyah & $\mathrm{P}$ & 40 & 60 & 70 \\
\hline & Jumlah & & 2220 & 2770 & 3240 \\
\hline & Rata-rata & & 55.95 & 69.30 & 80.93 \\
\hline
\end{tabular}

Tingkat pencapaian penguasaan materi Ilmu Pengetahuan Sosial tentang "Uang dan Lembaga Keuangan" yaitu hasil awal (Pra test) menunjukkan skor rata-rata sebesar 55,95, hasil pada siklus I naik menjadi skor rata-rata sebesar 69,30, hasil pada siklus II naik menjadi skor rata-rata sebesar 80,93.

Dengan demikian, meningkatnya nilai dari hasil evaluasi pelajaran IPS pada materi "Uang dan Lembaga Keuangan" pada tiap siklusnya, berarti pemahaman siswa kelas IXD SMP Negeri 2 Jamblang Kabupaten Cirebon terhadap materi tersebut menunjukkan adanya peningkatan yang cukup signifikan, hal ini dapat dilihat dari siswa yang memperoleh nilai di atas KKM 75.

\section{Simpulan}

Berdasarkan analisi data selama Siklus I dan II dapat disimpulkan terjadi peningkatan kemampuan siswa dalam pembelajaran IPS pada materi "Uang dan Lembaga Keuangan" dalam menggunakan Model Skrip Kooperatif baik secara kualitatif maupun kuantitatif dapat disimpulkan bahwa menerapkan model Skrip Kooperatif dalam proses pembelajaran IPS pada materi "Uang dan Lembaga Keuangan" dapat Meningkatkan Pemahaman siswa kelas IXD SMP Negeri 2 Jamblang Kabupaten Cirebon.

\section{Daftar Pustaka}

Adi, F. M., Phang, F. A., \& Yusof, K. M. (2012). Student Perceptions Change in a Chemical Engineering Class using Cooperative Problem Based Learning (CPBL). Procedia - Social and Behavioral Sciences, 56, 627-635. https://doi.org/10.1016/j.sbspro.2012.09.697

Arikunto, S. (2006). Prosedur Penelitian Tindakan Kelas. Bumi Aksara.

Aryati, T. (2017). Meningkatkan Aktivitas Dan Hasil Belajar Bahasa Indonesia Pada Materi Cerpen Melalui Penerapan Model Pembelajaran Kooperatif Bermain Jawaban Di Kelas Xi Ips 5 Sman 10 Pekanbaru. PeKA: Jurnal Pendidikan Ekonomi Akuntansi, 5(2), 172-177. https://doi.org/10.1017/CBO9781107415324.004 
Buchs, C., Gilles, I., Dutrévis, M., \& Butera, F. (2011). Pressure to cooperate: Is positive reward interdependence really needed in cooperative learning? British Journal of Educational Psychology. https://doi.org/10.1348/000709910X504799

Darojat, Q., Ani, H. M., \& Suyadi, B. (2018). Penerapan Model Pembelajaran Cooperative Script Untuk Meningkatkan Keaktifan Dan Hasil Belajar Siswa. Jumal Pendidikan Ekonomi: Jurnal Ilmiah Ilmu Pendidikan, Ilmu Ekonomi Dan Ilmu Sosial, 12(2), 207. https://doi.org/10.19184/jpe.v12i2.8321

Giri, K. Y. Y., Suarni, N. K., \& Arini, N. W. (2018). Pengaruh Model Pembelajaran Kooperatif Script Berbantuan Media Audio Visual terhadap Hasil Belajar IPS Kelas IV. E-Journal PGSD Universitas Pendidikan Ganesha, 6(1), 63-72.

Johnson, D. W., \& Johnson, R. T. (1999). Making cooperative learning work. Theory into Practice. https://doi.org/10.1080/00405849909543834

Kasbolah, K. (2001). Penelitian Tindakan Kelas (PTK). Malang: Depdikbud.

Kusumawati, I. T., \& Sukidi, M. (2014). Penerapan Model Pembelajaran Kooperatif Tipe Stad Untuk Meningkatkan Hasil Belajar Teknik Pengelasan Pada Siswa Kelas X .... JPGSD, 2(2), 1-12. Retrieved from http://digilib.unimed.ac.id/id/eprint/21704

Laal, M., \& Ghodsi, S. M. (2012). Benefits of collaborative learning. Procedia - Social and Behavioral Sciences. https://doi.org/10.1016/j.sbspro.2011.12.091

Laal, M., Khattami-Kermanshahi, Z., \& Laal, M. (2014). Teaching and Education; Collaborative Style. Procedia - Social and Behavioral Sciences. https://doi.org/10.1016/j.sbspro.2014.01.890

Lathifah, L. (2014). Meningkatkan Aktivitas Peserta Didik Dalam Pembelajaran Ips Melalui Metode Pembelajaran Cooperative Script Di Kelas Viii B Smp Negeri 2 Amuntai Selatan. Jurnal Socius, 3(2). https://doi.org/10.20527/jurnalsocius.v3i2.3270

Meilani, R., \& Sutarni, N. (2016). Penerapan Model Pembelajaran Cooperative Script Untuk Meningkatkan Hasil Belajar. Jurnal Pendidikan Manajemen Perkantoran, 1(1), 176. https://doi.org/10.17509/jpm.v1i1.3349

Oxford, R. L. (1997). Cooperative Learning, Collaborative Learning, and Interaction: Three Communicative Strands in the Language Classroom. The Modern Language Journal. https://doi.org/10.2307/328888

Salamiah. (2018). Penerapan Model Pembelajaran Kooperatif Tipe Script Untuk Meningkatkan Hasil Belajar Bahasa Indonesia Pada Materi Menyimak Cerita Siswa Kelas Vi Sd Negeri 020 Tembilahan Hilir. Jurnal PAJAR (Pendidikan Dan Pengajaran), 1(1), 1-10. https://doi.org/10.1017/CBO9781107415324.004

Sriarunrasmee, J., Suwannatthachote, P., \& Dachakupt, P. (2015). Virtual Field Trips with Inquiry learning and Critical Thinking Process: A Learning Model to Enhance Students' Science Learning Outcomes. Procedia - Social and Behavioral Sciences. https://doi.org/10.1016/j.sbspro.2015.07.226

Suryana, A. (2017). Implementasi Model Pembelajaran Cooperative Script Untuk Meningkatkan Keaktifan Dan Prestasi Belajar Sejarah Siswa (Penelitian Tindakan Kelas Pada Siswa SMAN 1 Baregbeg). Jurnal Artefak, 4(2), 135. https://doi.org/10.25157/ja.v4i2.907

Susanto, A. (2013). Teori Belajar Dan Pembelajaran Di Sekolah Dasat. Biomass Chem Eng.

Wardani. (2007). Penelitian Tindakan Kelas. Jakarta: Universitas Terbuka. 